\title{
The maintenance requirement of cows Energy balance experiments with rations of hay and of hay and concentrates
}

\author{
A. J. H. VAN ES and H. J. NIJKAMP \\ Institute of Animal Physiology, Wageningen, The Netherlands
}

\begin{abstract}
Summary
Energy, carbon and nitrogen balances were measured for five dry, non-pregnant cows fed at the maintenance level with ten rations of hay or hay and concentrates. The digestibility of the dry matter of the rations varied from 50.9 to 80.1 . The maintenance requirement for metabolisable energy increased with a lower digestibility of the ration and also slightly with a higher proportion of digestible energy of protein origin in the digested ration. This was so for rations with and without concentrates.

The first kind of increase was of the size found in our earlier work with hay and given by Breirem (1944), Blaxter (1962) and Armstrong (1964).

A tendency toward the second kind of increase was found in our earlier experiments and in those of Armstrong (1964).

Replacement in the regression computations of maintenance requirement for metabolisable energy at $500 \mathrm{~kg}$ body weight on rations or composition of rations, of the ten ration variables by $2-5$ variables such as digestibility of energy, crude protein content etc. of the ten rations, resulted in an approx. $30 \%$ higher residual sum of squares. A residual sum of squares more close to the residual sum obtained when the rations were used as ten separate variables might be got, if the contents of digested cellulose, digested hemicelluloses and digested other carbohydrates could have been used instead of digested crude fibre and digested $\mathrm{N}$-free extractives.

In the present experiments there was no significant change of maintenance requirement of the same animal in the course of time, nor were there significant carry-over effects. Comments are given on the influence of changes of the fill of the gastrointestinal tract on the maintenance requirement, and on the question whether it is allowed to accept a slightly higher residual error for predicted maintenance requirements by omitting the determination of digestibility.
\end{abstract}

\section{Introduction}

At many laboratories experiments to determine the maintenance requirement for metabolisable or net energy of cows and sheep have been performed. Usually either only hay or only mixed rations were the objects of the investigations. In this study the requirement on rations of hay is compared with the requirement on mixed rations of the same hay and concentrates.

\section{Experimental}

2.1. H a y s

In 1962 early and late cut hay was harvested from two fields and in 1963 from

Received for publication: October 13, 1965. 
Table 1. Details on hay making

\begin{tabular}{|c|c|c|c|c|c|c|c|}
\hline \multirow[t]{2}{*}{ Kind of hay } & \multirow[t]{2}{*}{ Field } & \multirow[t]{2}{*}{ Cut } & \multirow[t]{2}{*}{ Drying method } & \multicolumn{2}{|c|}{ Rain } & \multirow{2}{*}{$\begin{array}{l}\text { Brought } \\
\text { indoors }\end{array}$} & \multirow[t]{2}{*}{ Barndried } \\
\hline & & & & $\begin{array}{l}\text { while not } \\
\text { on tripods }\end{array}$ & $\begin{array}{c}\text { while } \\
\text { on tripods }\end{array}$ & & \\
\hline Early hay 1962 I & 1 & $1 . \mathrm{VI}$ & on tripods $6 . \mathrm{VI}$ & hardly any & much & 25.VII & no \\
\hline Late hay 1962 I & 1 & 7.VII & on tripods $10 . \mathrm{VII}$ & hardly any & much & 25.VII & no \\
\hline Early hay 1962 II & 6 & 4.VI & on tripods $7 . \mathrm{VI}$ & hardly any & much & 25.VII & no \\
\hline Late hay 1962 II & 6 & 9.VII & often turned & hardly any & & 23.VII & no \\
\hline Early hay 1963 & 14 & $1 . \mathrm{VI}$ & often turned & hardly any & & $5 . \mathrm{VI}$ & yes \\
\hline Late hay 1963 & 14 & 2.VII & often turned & hardly any & & 5.VII & yes \\
\hline
\end{tabular}

one field. Each field produced both an early and a late cut hay, the herbage being cut from alternative strips. Table 1 gives details on methods of hay making and weather.

\subsection{A n i m a I s}

Initially four dry, non-pregnant Friesian cows were used. After seven experiments animal Dora was replaced by animal Griet as the separation of urine and faeces with Dora was rather difficult. All animals were trained to the experimental routine before the experiments began. Their age during experiment $R 58$ was about 5 years. Animal 4 refused its feed in the preliminary period of experiment $R 54$, but recovered after a few days.

\subsection{Plan of experiments (Table 2)}

During the first four experiments (R 51-R 54) the hays 1962 II were fed to the four animals at the maintenance level, either alone or with cornmeal and groundnutmeal. In the latter case the amount of hay was reduced to $50 \%$ and such quantities of cornmeal and groundnutmeal were given so that the estimated quantities of digestible crude protein and digestible organic matter of the mixed ration were equal to those of the ration of hay alone.

During the next experiment ( $R 55$ ) only $50 \%$ of the rations of $\mathbf{R} 54$ was fed.

The experiments $R 56$ and $R 57$ consisted of a reversal trial with the early and late cut hay $1962 \mathrm{I}$, the hays were fed at the maintenance level.

In the experiments R 58-60 again hay 1962 I was used, this time either alone or with cornmeal and groundnutmeal in the same way as during $R$ 51-54 with hay 1962 II.

The experiments $\mathrm{R}$ 61-62 were meant to be a reversal difference trial with feeding levels at $1 \times$ maintenance and $11 / 2 \times$ maintenance with the early and late cut hay 1963. During a period of some days prior to the experiment the late cut hay was not eaten in a sufficient amount at the high level, therefore this level was reduced to the $1 / 2 \times$ maintenance level. During the experiments $R 63,64,65,68$ either the hays 1962 I or 1963 were fed at the maintenance level to study the variation in maintenance requirement with respect to time. During earlier experiments with hay rations higher requirements were sometimes found at the end of the stall-period and lower at its begining when the animals had been outdoors for some weeks (vaN Es et al., 1964). This effect may have been due to a deficiency or lack of exercise. Therefore copper, cobalt and vitamins $A$ and $D_{3}$ were added to the ration of two 


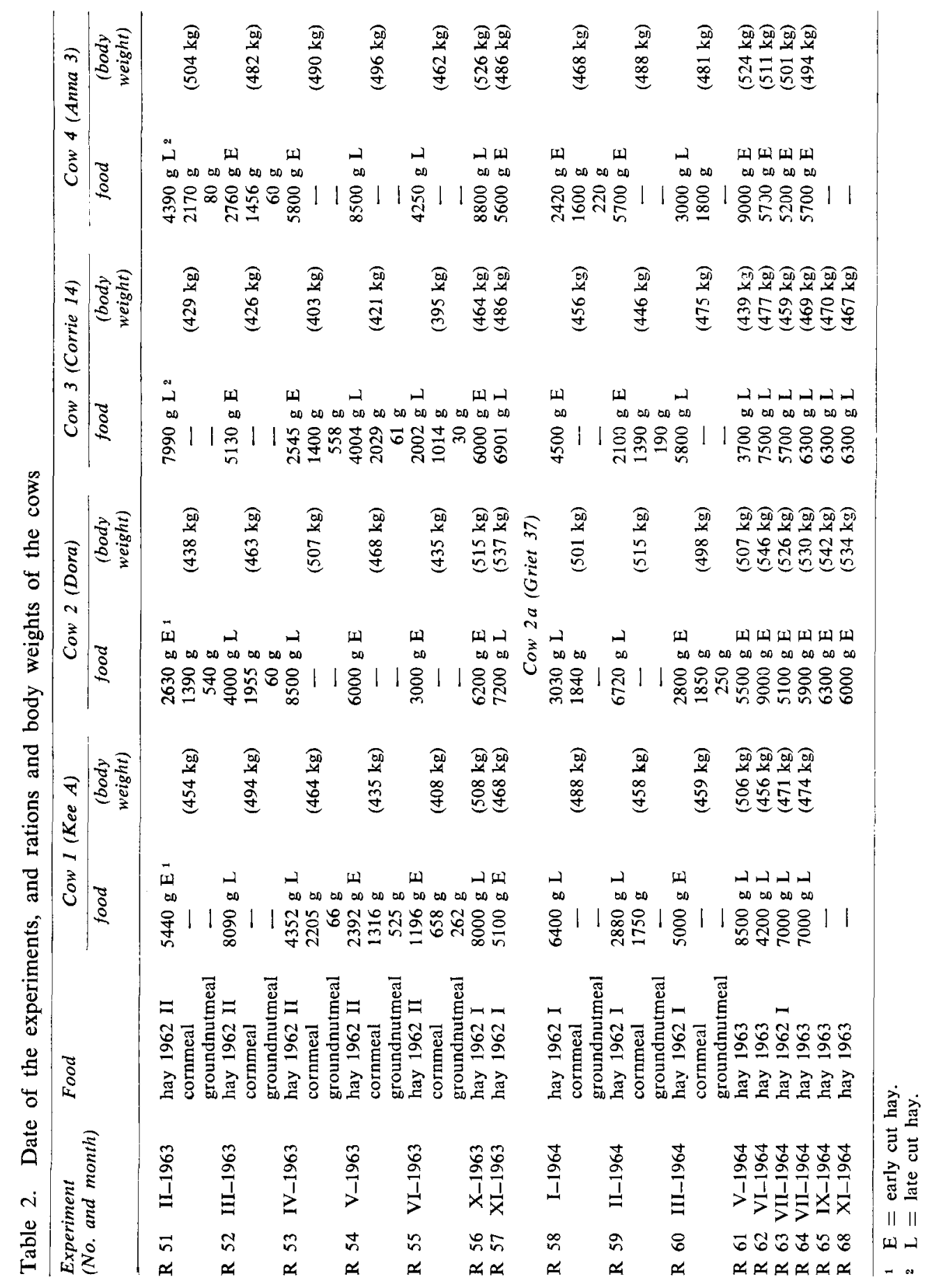




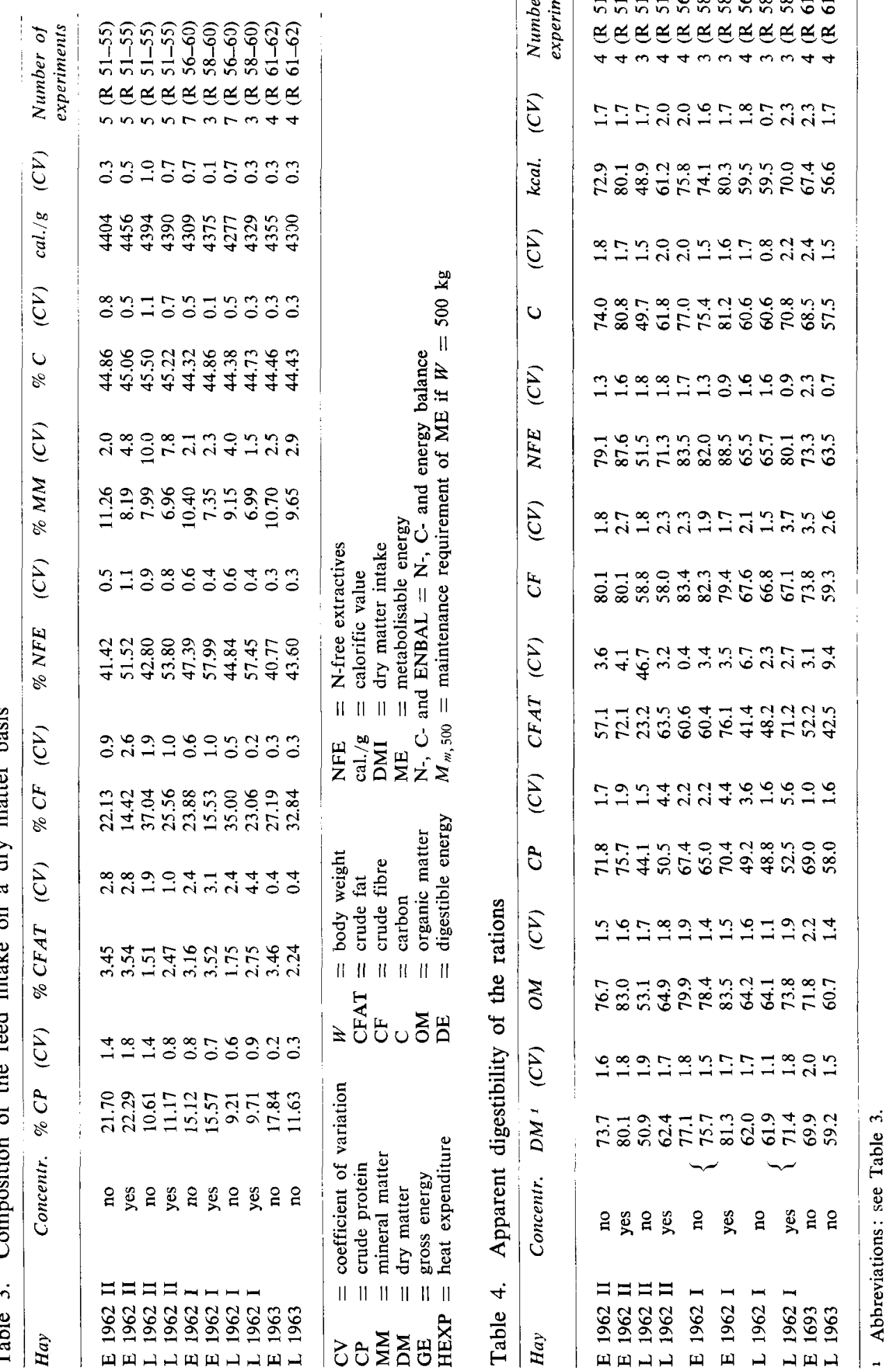


(No. 1 and No. 4) of the animals. The same two animals also were allowed free exercise in a paved yard outdoors ( $R$ 63, $R$ 64). The maintenance requirement of the animals 2 and 3 which remained indoors was determined once more in $R 65$ after the animals had been given small quantities of copper, cobalt and vitamins $A$ and $D_{3}$ in addition to their ration. Their maintenance requirement finally was determined in $\mathrm{R} 68$ after their having been at pasture for two months.

All animals were given daily $30 \mathrm{~g} \mathrm{NaCl}$.

\section{4. $\mathrm{M}$ e t h od s}

The preliminary and experimental periods of the experiments $R 51-55$ lasied 12 and 14 days, respectively, those of $R$ 56-62 19 and 16 days, respectively. In the experimental periods 2 24-hour respiration trials were performed three times with each animal. The preliminary and experimental periods of R 63-65 lasted 15 and 6 days, respectively, those of $R 6817$ and 5 days. Only 2 24-hour respiration trials were performed in these four experiments.

Technical and analytical methods as described earlier (vaN Es, 1961, 1966) have been used. In the experiments $R 63,64,65$ and 68 only dry matter intake, faecal dry matter and respiratory gasexchange were measured. From these data metabolisable energy, heat expenditure and average energy balance were computed with the aid of data obtained from the earlier completed balances in which the animals had been fed the same hays.

Factors and constants recommended by the 3rd Symposium on Energy Metabolism of the European Association of Animal Production, Troon, 1964, have been used.

\section{Results}

3.1. Composition, digestibility and metabolisability of the rations

Ration late hay 1962 II was not eaten completely, feed residues amounted to 5-15\% of the amount given. With all other rations no feed residues or only very small quantities were left. Table 3 gives the composition of the food taken in by the animals and also the coefficients of variation of the component percentages of the three to seven times that the same rations were fed to the animals. The coefficients of variation are low, although slightly higher than those found within an experiment. In the latter case only variation due to analysis and sampling is involved. In the present experiments there was another source of variation due to the fact that neither the concentrates nor the hay used for all experiments came from thoroughly mixed lots. Before the rations were weighed, usually for one, sometimes for two experiments, from the only roughly mixed big lots minor quantities of sufficient size were taken and mixed thoroughly.

There was a considerable difference in composition between the early and the late cut hays, the former having higher crude protein, crude fat and ash contents and lower crude fibre contents. The four rations with concentrates contained $0.5 \%$ more crude protein, $0.1-1.0 \%$ more crude fat, $8-12 \%$ less crude fibre, $10-13 \%$ more $\mathrm{N}$-free extractives and 1-3\% less ash than the corresponding four rations without concentrates.

The average apparent digestibilities of the rations are given in Table 4.

They are averages of results obtained with three or four different animals, their coef- 


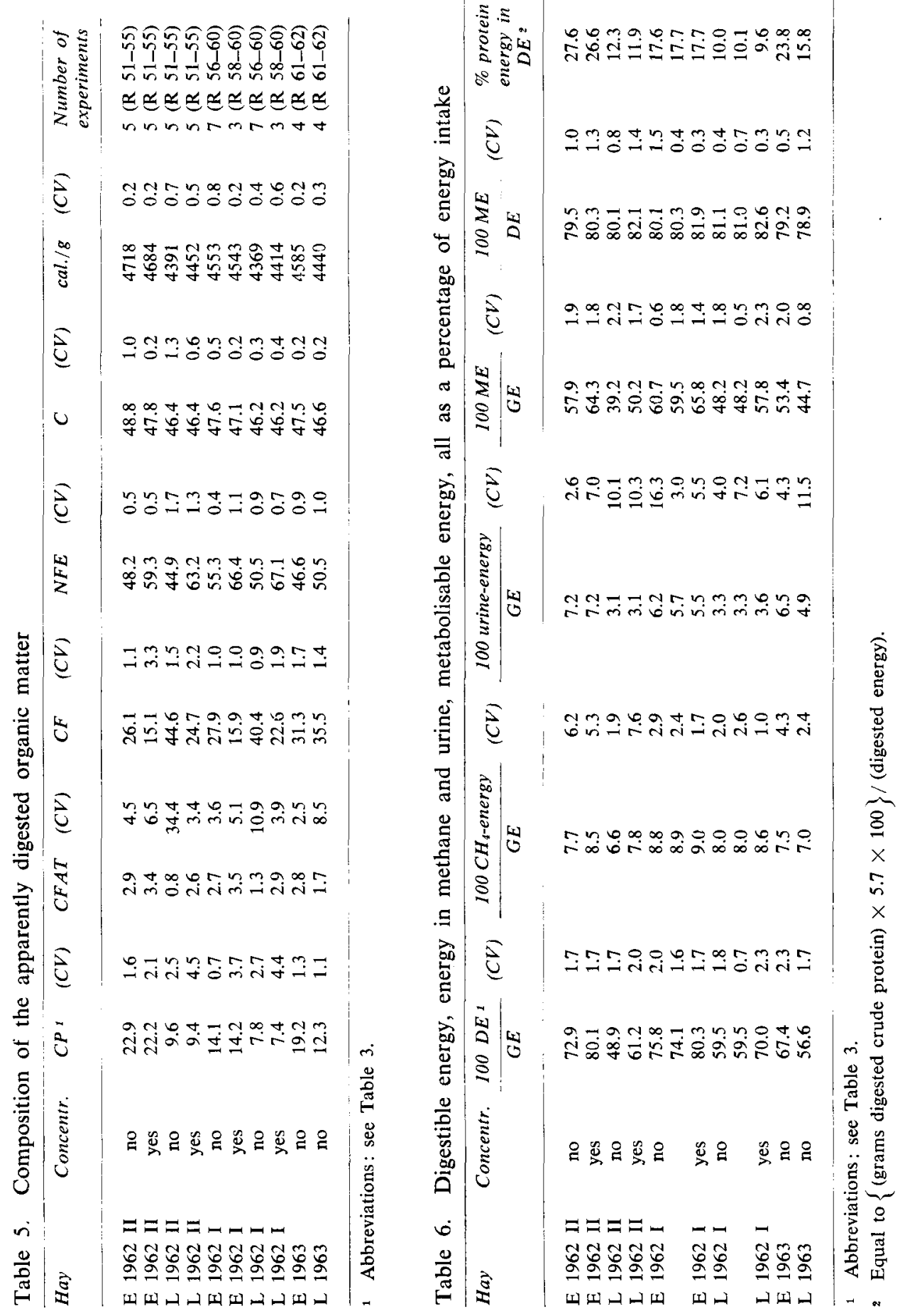


ficient of variation therefore also includes variation due to between-animal variation in digestibility. These coefficients of variation nevertheless are low. All components of the early cut hays were better digested than those of the corresponding late cut hays. The replacement of half of the hay by concentrates led to higher digestibilities of all components except crude fibre, the increase in digestibility of dry and organic matter, $\mathrm{N}$-free extractives, $\mathrm{C}$ and energy was greater for the late than for the early hays as might be expected. This replacement hardly changed the contents of crude protein, $\mathrm{C}$ and energy of the digested organic matter (Table 5), however, it decreased its content of crude fibre and it increased its content of $\mathrm{N}$-free extractives.

The digestibility of dry and organic matter, and of energy tended to be one or two units higher during the experiments with $1 / 2 \times$ maintenance rations $(R 55, R 61$ cow 3, R 62 cow 1). The digestibilities of all components of the late hay ration of cow 4 in $R 54$ were very low. This animal refused its feed in the preliminary period of this experiment but recovered after some days. In the further computations the results obtained with this animal in this experiment usually have been omitted. The digestibilities of the dry matter in the experiments $R \quad 63,64,65$ and 68 did not differ significantly from those of corresponding rations in earlier experiments.

The average energy losses due to methane and urine and also the contents of metabolisable energy as a percentage of energy intake of the rations are given in Table 6 . Replacement of half of the hay of the ration by concentrates tended to increase the percentage of gross energy lost as methane. It also increased the ratio $100 \mathrm{ME} / \mathrm{DE}$ by about one unit. Higher urinary energy losses occurred with the early cut hays than with the late cut hays, a fact found earlier (BRouwer et al., 1964).

\subsection{Regression of digestible and metabolisable energy on digested components of the rations}

The multiple regression of digestible energy $\left(y_{1}, \mathrm{kcal}\right.$.) or metabolisable energy $\left(y_{2}\right.$, $\mathrm{kcal}$.) on digested crude protein $\left(x_{1}, \mathrm{~g}\right)$, digested crude fat $\left(x_{2}, \mathrm{~g}\right)$, digested crude fibre $\left(x_{3}, \mathrm{~g}\right)$ and digested $\mathrm{N}$-free extractives $\left(x_{4}, \mathrm{~g}\right)$ was computed with and without a constant. This has been done with all 205 maintenance experiments so far performed at this laboratory ( $R$ 1-62), of which 136 were rations of hay and 69 rations of hay and concentrates:

Regression equation

$$
\begin{aligned}
& y_{1}=6.23 x_{1}+5.71 x_{2}+4.03 x_{3}+4.56 x_{4}-476 \quad 140 \quad 0.8 \quad 136 \text { hay } \\
& y_{1}=5.93 x_{1}+7.50 x_{2}+3.97 x_{3}+4.36 x_{4} \quad 147 \quad 0.8 \quad 136 \text { hay } \\
& y_{1}=5.74 x_{1}+9.32 x_{2}+4.49 x_{3}+3.87 x_{4}+381 \quad 88 \quad 0.5 \quad 69 \text { hay }+ \text { conc. } \\
& y_{1}=5.70 x_{1}+11.70 x_{2}+4.48 x_{3}+3.94 x_{4} \quad 109 \quad 0.6 \quad 69 \text { hay }+ \text { conc. } \\
& y_{1}=5.81 x_{1}+9.33 x_{2}+4.12 x_{3}+4.13 x_{4}+118 \quad 145 \quad 0.8 \quad 205 \text { all rations } \\
& y_{2}=4.45 x_{1}+5.91 x_{2}+3.21 x_{3}+3.73 x_{4}-457 \quad 215 \quad 1.6 \quad 136 \text { hay } \\
& y_{2}=3.76 x_{1}+10.53 x_{2}+2.96 x_{3}+3.79 x_{4}-406 \quad 124 \quad 0.9 \quad 69 \text { hay }+ \text { conc. } \\
& y_{2}=4.27 x_{1}+6.97 x_{2}+3.16 x_{3}+3.72 x_{4}-341 \quad 192 \quad 1.4 \quad 205 \text { all rations }
\end{aligned}
$$


All regression coefficients were statistically significant. The standard deviations of these coefficients of the $y_{1}$-equations were less than 0.1 for the hay rations, less than 0.2 for $x_{1}, 1.1$ for $x_{2}$ and 0.1 for $x_{3}$ and $x_{4}$ for the mixed rations. These coefficients of the $y_{1}$-equations are close to the calorific values of protein, fat and carbohydrates. Similar results were obtained by SchiemanN et al. (1963) with concentrates. It is clear that digestible and metabolisable energy may be computed with high precision from the digestible components $x_{1}-x_{4}$ of the ration.

\subsection{The N-, C- and energy balances}

The main data on the balances of all experiments are given in Table 7. A limited number of the complete balance sheets (VAN Es, 1966) may be obtained at request.

Except for those of the experiments with rations fed at $1 / 2$ or $1 \frac{1}{2}$ times the maintenance level and of cow 4 in $R 54$, none of the balances differed considerably from zero (N-balance: +11 to $-9 \mathrm{~g}$; C-balance: +184 to $-130 \mathrm{~g}$; energy balance: +2122 to $-1698 \mathrm{kcal}$.).

As in earlier experiments there was a difference of $1-2 \%$ of the energy intake between the energy balance computed from $\mathrm{C}$ - and $\mathrm{N}$-balance and the energy balance computed from metabolisable energy and heat expenditure.

\subsection{The maintenance requirement of metabolisable} e n e r g y

To obtain comparable data on the requirement of metabolisable energy for maintenance, the measured intakes of metabolisable energy should be corrected to zero energy balance and converted to figures applying to animals with equal body weight.

Some information on factors for correction to zero energy balance might be obtained from the experiments with $1 / 2$ and $1 \frac{1}{2}$ times maintenance rations together with the experiments with maintenance rations which immediately preceded or followed them (R 54 and 55 with animals $1-3, \mathrm{R} 61$ and 62 with animals $1,2 \mathrm{a}, 3$ and 4 ; experiments R 54 and 55 with animal 4 were excluded because of the abnormally low digestibility and high heat expenditure of this animal in $\mathrm{R} 54$; in the preliminary period of this experiment the animal had refused food for some days). Thus the number of available difference trials was five below and two above energy equilibrium. In the case that one of the two experiments of a difference trial had a positive and the other a negative energy balance it was assumed that the efficiency of the utilisation of metabolisable energy for lipogenesis was roughly 0.8 times the efficiency for maintenance; thus the balance having the smallest absolute value was either multiplied or divided by 0.8 . Correction for differences in body weight in both parts of a difference trial was done by using the 0.75 power. The efficiencies for maintenance of the rations early hay 1962 II without and with concentrates, late hay 1962 II with concentrates and (twice) late hay 1963 were $71,63,63,56$ and $66 \%$, respectively, those for lipogenesis of the ration early hay 1963 (twice) were 51 and $54 \%$. Without a correction for differences in body weight lower values by 5-7 units and in one case by 3 units were obtained.

As mentioned above in the experiments with rations fed at the maintenance level, most energy balances were small, therefore correction of intake of metabolisable energy to zero energy balance with slightly incorrect efficiency-values would hardly invalidate the results. It was concluded that an efficiency of the utilization of metabolisable energy of $50 \%$ in the case of positive balances and one $66.7 \%$ in the 


\begin{tabular}{|c|c|c|c|c|c|c|}
\hline & $\begin{array}{l}\left(l^{p o y}\right) \\
\operatorname{ooc}^{\circ}{ }^{\prime \prime u} W\end{array}$ & 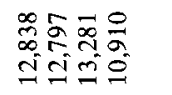 & 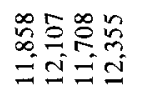 & 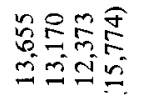 & 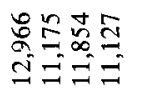 & 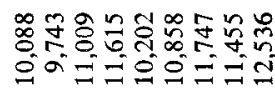 \\
\hline & $\begin{array}{c}(8 y) \\
M\end{array}$ & 䢘守条总尔 & 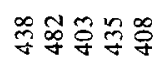 & 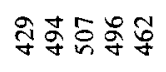 & 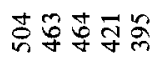 & 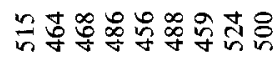 \\
\hline & $\left.(\cdot)^{p ว y}\right)$ & 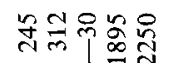 & 号 & 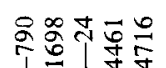 & $+\frac{\infty}{2} 88$ & 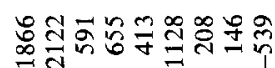 \\
\hline & $: 7 V 8 N \exists$ & $-\hat{\imath}$ & & Tि & & \\
\hline & (8) & $\bar{m} \dot{m} \underset{0}{0}$ & 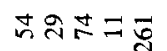 & 욤웡 & N68응 & 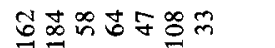 \\
\hline & $7 \forall g-3$ & & & $1 \uparrow$ & & \\
\hline & $(8)$ & $N O+=N$ & mano & & & $+m-n n \pi n$ \\
\hline & $7 V g-N$ & & & & 1 & \\
\hline & $(j p x y)$ & $m 6+2 \alpha$ & 8ning & 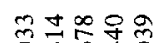 & 음ํㅇㅇㅇ & "๐2 \\
\hline & dXJH & 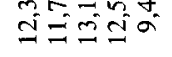 & $=0$ & 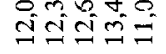 & $\bar{m}=\bar{c}=\bar{\infty}^{-}$ & 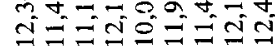 \\
\hline & (\%) & 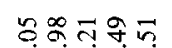 & f 800 & ํํ응ำ & $7820 \%$ & 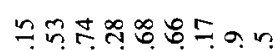 \\
\hline & $39 / 3 W$ & 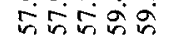 & $\dot{0} 8308$ & 舟品守向 & 它品京品的 & 68888000 \\
\hline & & $2 \approx 5 \approx \infty$ & $925 \overline{0}$ & $a ̊ 0_{\infty}^{\infty}=$ & $\forall \infty 9 S^{\infty}$ & 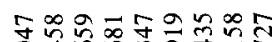 \\
\hline & $3 W$ & 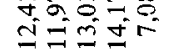 & $\begin{array}{l}0 \mathrm{H}=\mathrm{m} \\
=\mathrm{N}=\mathrm{m}\end{array}$ & 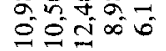 & ปे=ง & 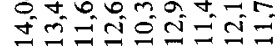 \\
\hline & $(\%)$ & สร็ & 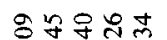 & $\because \approx 28$ & テニ踤さ & 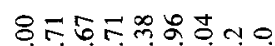 \\
\hline & $39 / 30$ & 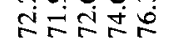 & $\infty \infty \infty \infty \infty$ & $\stackrel{\infty}{+} \stackrel{\infty}{q} g$ & ช่ธ்่ & 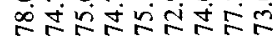 \\
\hline & & 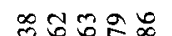 & 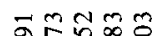 & $g \approx F ⿻ 上$ & 동요 & 으우웅ㅁㅁㅇㅇㅇ \\
\hline & $\begin{array}{l}3 a \\
7 a\end{array}$ & 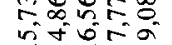 & 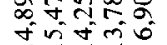 & minis & 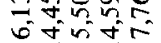 & $\begin{array}{l}50 \\
=0+000\end{array}$ \\
\hline & & & & & & \\
\hline & $\left(\eta^{\text {DOY }}\right)$ & 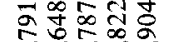 & ర루용ㅇㅇ & 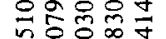 & సै: & 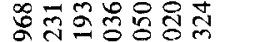 \\
\hline & 39 & तิ & $\infty 2 \infty 0$ & 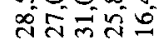 & งิง สิ & กี่งลี่ \\
\hline & (WG $u ! \%)$ & 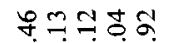 & ․ㅜㅇㅛ & 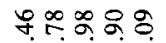 & 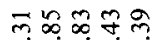 & $\infty \infty F \circ \infty$ \\
\hline & tS & तં & $\dot{ \pm} \dot{ \pm} \dot{ \pm} \dot{ \pm} \dot{ \pm}$ & 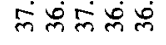 & ลู่อั & $\dot{i} \dot{N}$ \\
\hline & $(w a$ l $u$ \% & 용ํำ & 吉吉导年 & 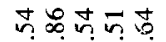 & ণิ & 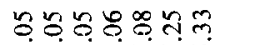 \\
\hline & $d S$ & $\dot{\vec{N}} \overrightarrow{\mathrm{N}} \dot{\vec{N}} \dot{\vec{N}} \dot{\vec{N}}$ & สี่ี่ & $\Leftrightarrow \dot{9} 9$ & $\dot{\Xi} \dot{\Xi} \dot{\Xi}$ & ningn \\
\hline & (8) & \&®せ゚ & $\because 558 \infty$ & 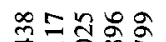 & 웜ㅎํ & 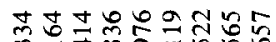 \\
\hline & $I W a$ & 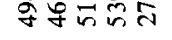 & $\mp 99 \infty$ & Jै & nहnं & 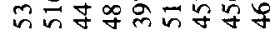 \\
\hline & & & & & & \\
\hline & พ & $-m \nabla N N$ & $N \rightarrow m-r$ & $m \pi n \theta$ & $\nabla N-m m$ & $\begin{array}{c}+ \\
\infty \\
\infty\end{array}$ \\
\hline E & 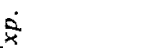 & 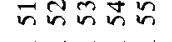 & 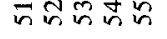 & 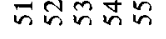 & 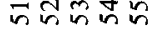 & 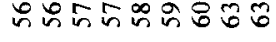 \\
\hline$\stackrel{\mathscr{S}}{\mathrm{U}}$ & $\hat{y}$ & $\simeq \simeq \simeq \simeq \simeq$ & $\simeq \approx \simeq \simeq \simeq$ & $\simeq \simeq \simeq \simeq \approx$ & $\simeq_{1} \simeq_{1} \simeq_{1} \simeq_{1} \simeq_{1}$ & $\simeq \simeq \simeq \simeq \simeq \simeq \simeq \simeq \simeq$ \\
\hline ตี & छ் & 1 & + & l & + & 1 \\
\hline & & $\Xi$ & $=$ & $\Xi$ & $\Xi$ & - \\
\hline & & ชิ & రै & ชै & గิ & S \\
\hline & & ш & Ш & ــ & & 띠 \\
\hline
\end{tabular}




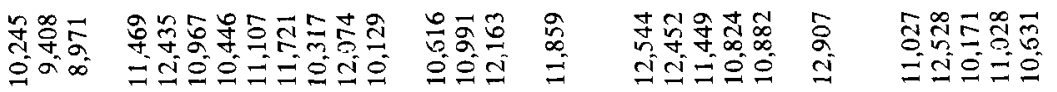

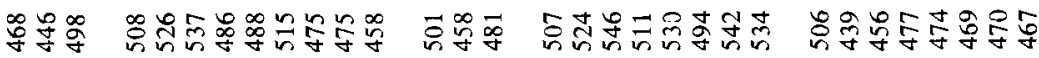

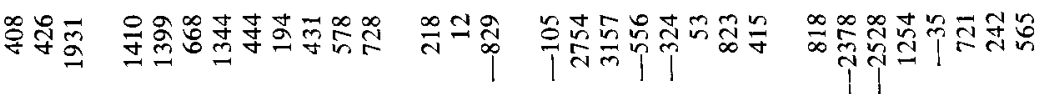

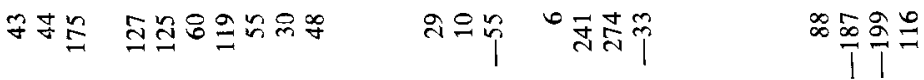

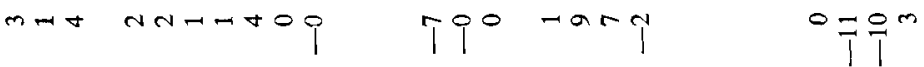

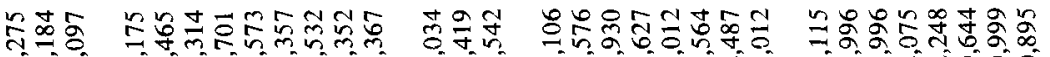

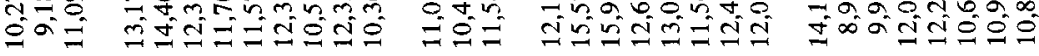

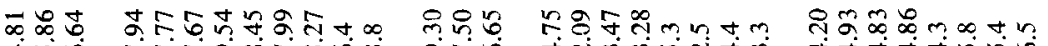

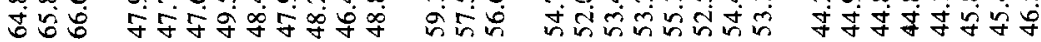

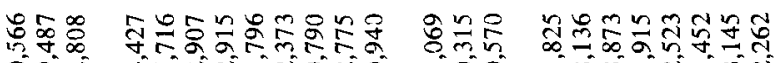

oำ

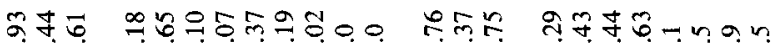

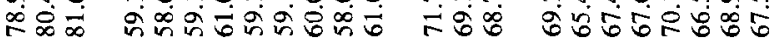

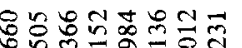

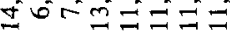

กิ

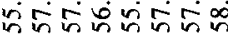

이요요

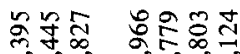

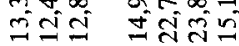

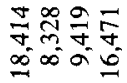

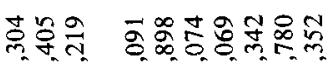

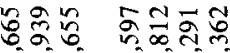

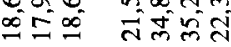

ชำㄴำ

लें

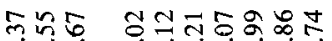

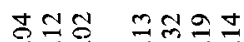

$2 \pm \infty \infty$

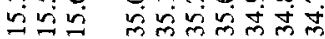

बुलि तथल

लुल्लंलूल

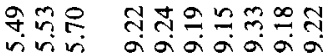

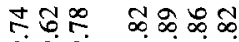

बंब

$\infty 80$

$\Xi \Xi \Xi \Xi$

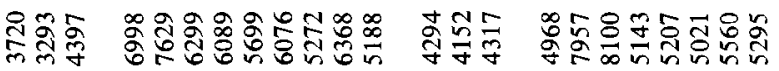

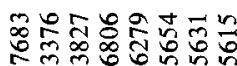

tm

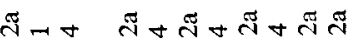

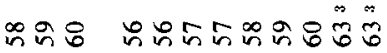

in

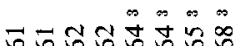

$-m-m-m m m$

$\simeq \propto \simeq \quad \simeq \simeq \simeq \simeq \simeq \simeq \simeq \simeq \propto$

$\simeq \simeq \simeq \simeq \simeq \simeq \simeq \simeq \simeq \simeq \simeq$

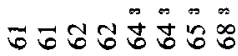

$\simeq \simeq \simeq \simeq \simeq \simeq \simeq \simeq$

$+$
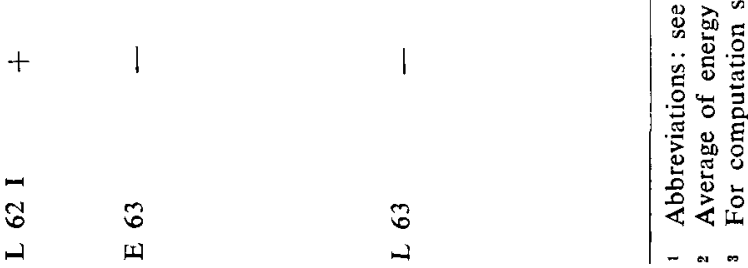

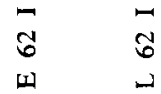

สู้

$\hat{6}$

3

Neth. J. Agric. Sci., Vol. 14 (1966) No. 3 (August) 
rations (all except $R 54$ with animal 4) neither carry-over, nor period variation were significant, in contrast to animal and ration variation which were significant. In the following computations therefore attention was only paid to animal and ration variation. The twelve results of the experiments $R 63,64,65$ and 68 were excluded as these experiments were of a shorter length and were only performed to study period variation. There remained 39 results obtained with five animals and ten rations. To see whether the assumption that the influence of the choice of the factors used in correcting intake of metabolisable energy for energy balance and body weight differences was small, was in fact correct, nine differently computed sets of values $M_{m, 500}$ were regressed on general mean, animals and rations (Table 8). The correction for energy balance in these sets was calculated either assuming $50 \%$ and $67 \%$ efficiencies of the utilization of ME for gain and loss, respectively, or assuming efficiencies of $0.75 \times \% \mathrm{DE}-4$ (derived from BLAXTER, 1962, p. 247) and $0.3 \times \% \mathrm{DE}$ +50.9 (derived from ARMSTRONG, 1964, p. 410), respectively, or efficiencies of $-0.7 \times \% \mathrm{CF}+65.6$ (analysis of BreIREM, 1944) and $-0.5 \times \% \mathrm{CF}+80$ (derived from Brouwer et al., 1964, p. 63), respectively.

The correction for body weight was calculated using the powers $0.6,0.75$ and 1.0. Table 8 shows that the choice of the correction factors hardly influenced the results of the regression computation. The regression coefficients with the corrections 50/ $67 \%$ and 0.75 were:

Mean $11,555 \pm 96 \mathrm{kcal}$.

Cows $328,-671,-46,-428,817$ ( \pm approx. 200) kcal.

Rations E 62 II 890; L 62 II 1768; E+ 62 II 442; L+ 62 II 215

E 62 I $-912 ; \mathrm{L} 62 \mathrm{I}-331 ; \mathrm{E}+62 \mathrm{I}-2128 ; \mathrm{L}+62 \mathrm{I}-665$

E 63259 ; L 63462 ( \pm approx. 250) kcal.

The regressioncoefficients for the other sets differed at the most by approx. $100 \mathrm{kcal}$. for mean and cows and by approx. $200 \mathrm{kcal}$. for rations. Their standard deviations were of the same size as those of the above mentioned set.

The influence of the composition of the ration on the maintenance requirement in the regression computations was studied by replacing the ten rations by their contents of 2-5 components. Five combinations of components were used:

a. \% DE of GE, \% protein kcal. of $\mathrm{DE}$ and presence or absence of concentrates,

$b$. equal to $a$ minus concentrates,

c. \% crude fibre, \% crude protein, both in dry matter taken in, presence or absence of concentrates,

$d$. equal to $c$ minus concentrates,

$e$. \% digestible crude protein, $\%$ digestible crude fat, $\%$ digestible crude fibre, $\%$ digestible $\mathrm{N}$-free extractives and \% crude fibre of the dry matter intake.

Prior to the regression computation from each of these percentages of an experiment its average value in all experiments was subtracted. The average values were: $\%$ DE of GE 67.81 ; \% protein kcal. of DE 16.89 ; \% crude fibre 25.88 ; \% crude protein $14.30 ; \%$ digestible crude protein 9.08 ; $\%$ digestible crude fat $1.62 ; \%$ digestible crude fibre 18.17; and \% digestible $\mathrm{N}$-free extract 36.42. Table 9 shows the results of these computations. The residual sums of squares, especially those of method $d$, are higher than those of the earlier method. It is clear that in this respect none 


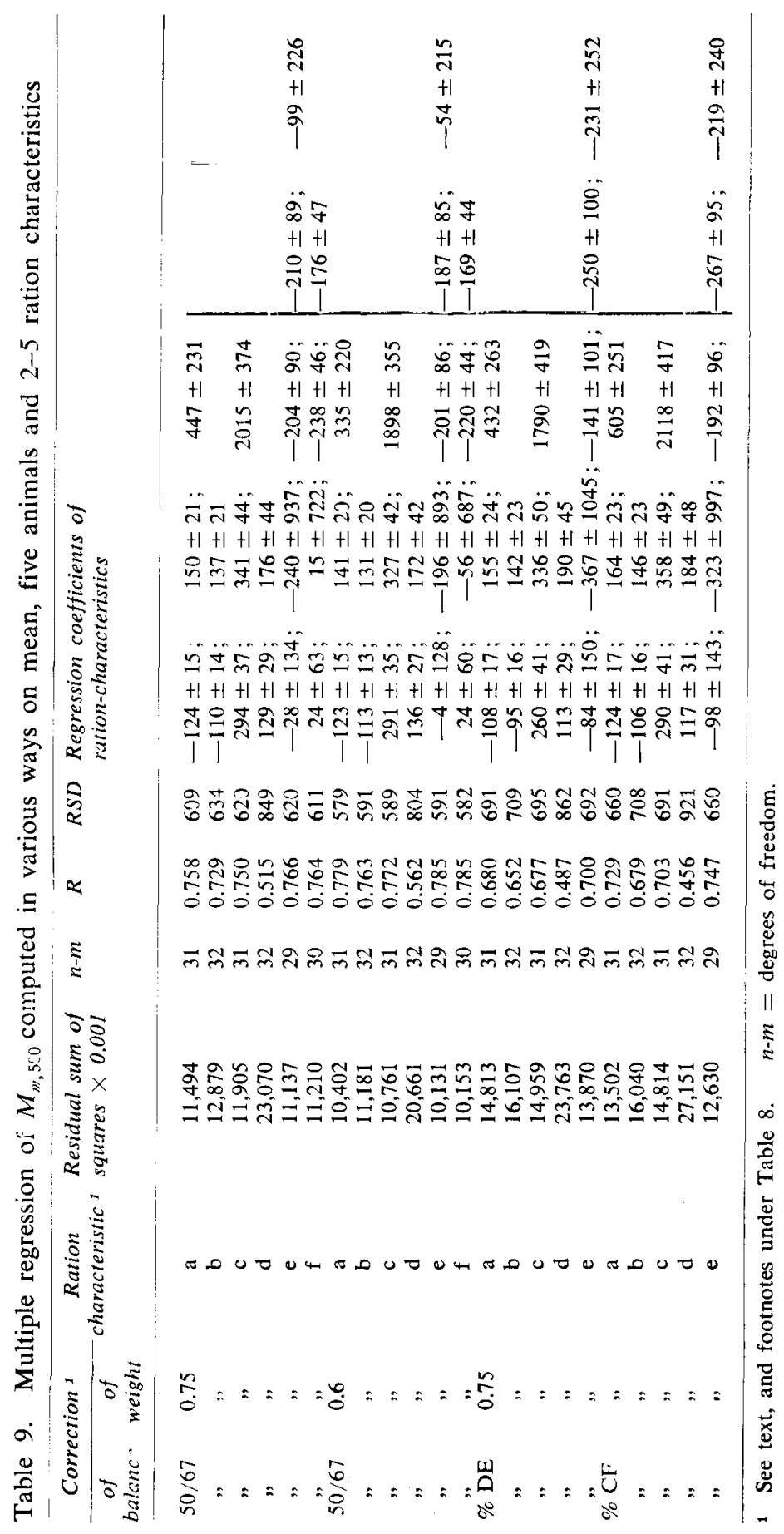


of the five combinations of component-contents could replace the rations completely The combinations $a, b, c$ and $e$ could replace them to a considerable extent. With the corrections $50 / 67 \%$ and 0.75 the residual sum of squares after mean and cows was $38,600,000$, after mean, cows and rations was 7,002,000 and after mean, cows and contents of ration $a, b, c$ or $e$ was about $12,000,000$. Figures of similar size were obtained with the other corrections.

It is interesting to compare the results obtained above with the results from earlier maintenance experiments with rations of hay. In these experiments there was significant period variation, especially if the maintenance requirements of net energy of the same animals in all experiments were supposed to be equal. If these maintenance requirements were supposed to be equal in up to five successive experiments, lasting at the most half a year period variation was less marked. As there were a larger number of animals and many different rations used, it was not possible to treat the results of the earlier experiments in the same manner as those of the present experiments. Therefore both sets were treated in a simpler way. The correction for energy balance was calculated using the efficiencies of utilization of the metabolisable energy for gain and for loss having values of 50 and $67 \%$, respectively. The correction for body weight was done using the power 0.75 . Furthermore it was assumed that the maintenance requirements of net energy for an animal, corrected to a body weight of $500 \mathrm{~kg}$, remained equal for at the most six successive experiments. The resulting maintenance requirements $M_{n, 500}$ were treated with multiple regression, with mean, cows, periods, \% DE of GE, and \% protein kcal. of DE as independent variables (Table 10).

The regression coefficients of the latter two variables were:

$R \quad 16-41-96 \pm 38$ and $51 \pm 60 \mathrm{kcal}$. (8 early and late hays)

R 42-50-74 \pm 64 and $44 \pm 51 \mathrm{kcal}$. (6 hays, neither early nor late)

R 51-68 $-76 \pm 25$ and $79 \pm 41 \mathrm{kcal}$. (6 early and late hays and mixed rations). As far as these variables are concerned there is little difference between the three series of experiments. All three had significant animal variation. The first and second series also had significant period variation, even though the results of the same cow which had been used during ten experiments (e.g. six successive ones in autumn and winter and four successive ones in early summer) have been used as if derived from two cows, i.e. six experiments with one and four experiments with the other animal.

Similar results were obtained using another simpler method. To avoid the influence of variation due to cows and to period, instead of one common mean, variable means were used, i.e. each cow had in two experiments its own mean (regression with variable level). The regression coefficients of the variables \% DE of GE (a) and \% protein kcal. of $\mathrm{DE}(b)$ were:

R $16-41-76 \pm 15$ and $27 \pm 25$ kcal. $(\bar{a}=64.0 ; b=18.8 ;$ RSD 552)
R $42-50-21 \pm 39$ and $21 \pm 26$ kcal. $(\vec{a}=60.2 ; b=13.7 ;$ RSD 488)
R $51-62-95 \pm 15$ and $95 \pm 25$ kcal. $(\bar{a}=67.8 ; b=16.6 ;$ RSD 539)
R $16-62-79 \pm 10$ and $50 \pm 15$ kcal. $(a=64.3 ; b=16.8 ;$ RSD 540)

Without \% protein $\mathrm{kcal}$. of $\mathrm{DE}$ as an independent variable the regression coefficients of $\% \mathrm{DE}$ of $\mathrm{GE}$ were:
R $16-41-62 \pm 9$ (RSD 553)
R $42-50-25 \pm 33$ (RSD 484)
R $51-62-50 \pm 10($ RSD 648$)$
R $16-62-55 \pm 7$ (RSD 569) 
A. J. H. VAN ES AND H. J. NIJKAMP

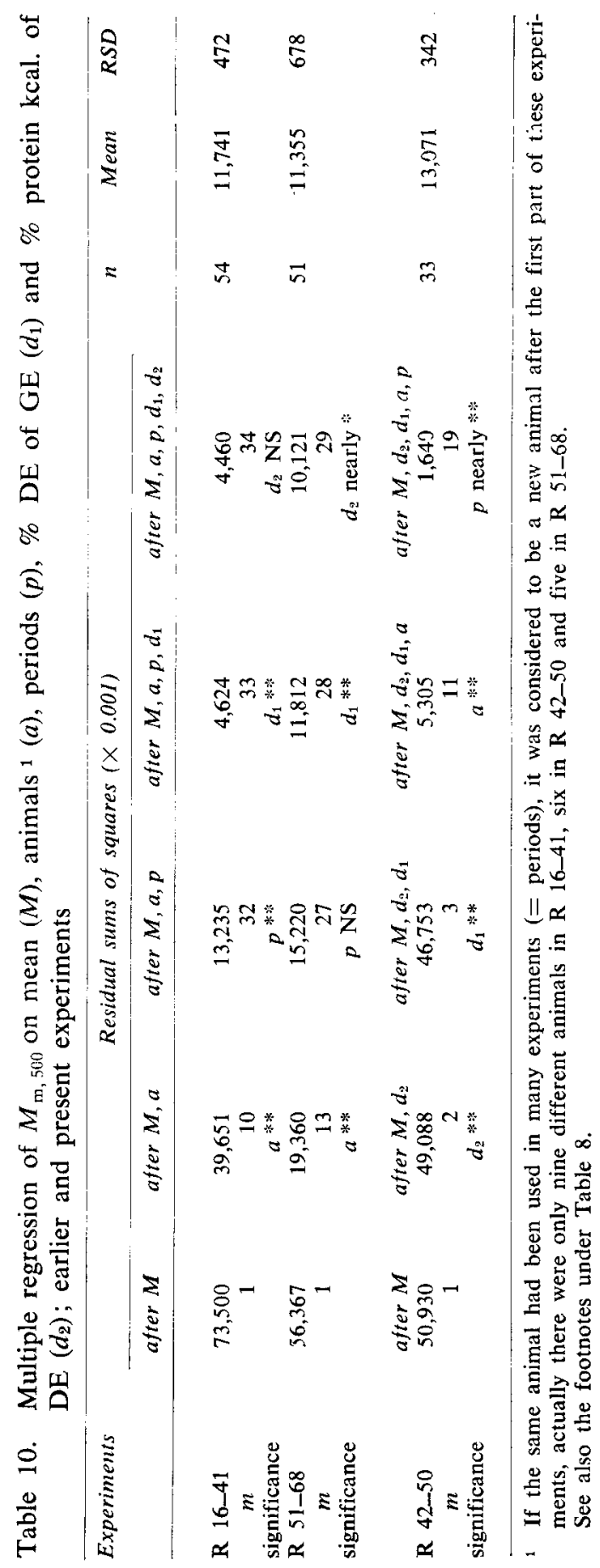


If metabolisability $(a$ ) and 6.25 times $\mathrm{g}$ urinary $\mathrm{N}$, corrected to a body weight of $500 \mathrm{~kg}(b)$, were used as independent variables the coefficients were:

R 16-62 -95 \pm 11 and $1.42 \pm 0.21 \mathrm{kcal}$. $(\bar{a}=51.2 ; \bar{b}=466$; RSD 531), with only $a$ as the independent variable the regression coefficient was $-72 \pm 8$ with RSD 555.

With $a=$ digestibility of dry matter and $b=$ percentage of digestible protein in the dry matter in the food, the coefficients were:

R 16-62-104 \pm 2 and $109 \pm 31$ kcal. $(\bar{a}=66.5 ; \bar{b}=8.5$; RSD 540), with only $a$ the regression coefficient was $-58 \pm 7$ and the RSD 571 .

With $a=\%$ crude fibre of dry matter in the food and $b=\%$ digestible crude protein of dry matter in the food, the coefficients were:

R 16-62 $101 \pm 16$ and $35 \pm 24 \mathrm{kcal}$. (RSD 566), the RSD was 563 if only crude fibre was used.

Finally with five variables (percentages digestible crude protein, digestible crude fat, digestible crude fibre and digestible $\mathrm{N}$-free extractives of food dry matter, and percentage of crude fibre in dry matter of food) the coefficients were:

$R$ 16-62 $21 \pm 52,661 \pm 303,-170 \pm 54,-94 \pm 32$ and $132 \pm 72$ kcal. (RSD 522).

Again it is not very important which components are used to indicate the properties of each ration.

\section{Discussion}

\subsection{Maintenance requirement and small differences of body we ight}

Differences in body weight of an animal may result from changes in fill of the gastrointestinal tract and from changes in the amount of tissue present which are due to nutrition being below or above the requirement for maintenance and milk. The second kind of changes involves changes in maintenance requirement, corrections for such changes are usually made in proportion to powers of the body weight which may vary from 0.6 to 1.0 . Whether the first change involves changes in maintenance requirement, is not accurately known. BLAXTER (1964, personal communication) assumes that these changes are very small and may be neglected. In our opinion these changes are greater, as to move and to carry a heavier content of the gastrointestinal tract will require additional energy. We therefore prefer to correct also for these changes in body weight using the same power as is used for correcting for the change in the amount of tissue. In practice this has the advantage that measured or estimated body weights may be used in the computation of the requirements, it is thus not necessary to correct for by estimating the content of the gastrointestinal tract. In the analysis of the results of difference trials, e.g. trials with the same ration fed at two or more feeding levels, most investigators correct for changes in body weight, some with the power 1.0 , others with the power 0.75 . If the separate experiments in such trials are of a short duration, the changes in body weight from one experiment to another will mainly be due to changes in content of gastrointestinal tract. Blaxter, using experiments of such duration, therefore, does not correct for body weight changes. As our opinion differs from his on this point we prefer not to neglect these differences in body weight. 


\subsection{Period variation of maintenance requirement}

Period variation of maintenance requirement, i.e. variation in the requirements for net energy with the same animal per $500 \mathrm{~kg}$ body weight with time, may be due to various causes. Excitement may increase the requirement, e.g. when untrained animals are brought into a respiration chamber which is built in such a way that one animal cannot see or smell other animals. Animals which have been partly accustomed to the experimental routine of experiments using respiration chambers often have up to $10 \%$ higher mainentance requirements, even after two or three weeks of training. About one quarter of the experiments R 16-41 were performed with such poorly trained animals; this may explain some of the period variation found in these trials. Prolonged feeding of rations which are deficient in one or more vitamins, minerals, or trace-elements will probably also result in less efficient utilization of metabolisable energy, resulting in higher requirements. This may have been the case during the experiments R 42-50 in which only hay of moderate quality was fed. After about five months a considerable increase in maintenance requirement was observed with all the cows. This effect lasted until the end of the series of experiments. The same animals again had lower requirements in other experiments which were performed after they had been out at pasture for some weeks. No significant period variation was observed in the present experiments during which rations of excellent and moderate hay and also rations of hay and concentrates were fed. In this series, moreover, the percentage of experiments performed using poorly trained animals was small. In a later series of experiments initiated in September 1964 no period variation has yet been observed (July 1965). In this series mixed rations with additions of vitamins, minerals and trace-elements in the manner generally used in practice were fed, moreover the animals were allowed some exercise in a paved yard for 6 hours per day during a week in the preliminary period of each experiment.

\subsection{The residual standard deviation}

The residual standard deviations (RSD) of the regression computations of section 3.4., vary from 500 to $600 \mathrm{kcal}$, i.e. from 4-6\% of the average maintenance requirement of the metabolisable energy for a cow of $500 \mathrm{~kg}$. A large part of this deviation is due to analytical and physiological errors. The intake of metabolisable energy usually has a standard deviation of $1-1.5 \%$ of the gross energy, i.e. 200-300 kcal. (see Table 6; also Brouwer et al., 1964, p. 63). One 24-hour determination of the heat expenditure has a coefficient of variation of 3-5\%, which results in a coefficient of variation of 1.5-2.5\% for the average heat expenditure during 4 days, i.e. 180$300 \mathrm{kcal}$. The energy balance thus has an error of about $300-400 \mathrm{kcal}$. The correction of the intake of metabolisable energy to zero energy balance may introduce considerable additional error if the energy balance differs much from zero, and if the factors to be used for this correction are not known accurately. Finally the correction of intake of metabolisable energy for maintenance to a common body weight leads to an additional error as the measured body weight is not free from error. RSD's of the size found in the computations of section 3.4. might therefore be expected. Considering the animal itself only part of the total variation is important, e.g. small changes in its ability to digest the same food with time alter its daily supply of digested energy. Similar changes in its ability to convert digested energy into net energy alter its daily supply of net energy, and finally its maintenance requirement may change due to excitement, illness etc. A considerable part of the total variation consists of measure- 
ment errors, made while determining composition, digestibility, heat expenditure, body weight and correction factors.

It is clear from the regressions on digestible dry matter etc. and on crude fibre near the end of section 3.4., that the maintenance requirement for metabolisable energy per $500 \mathrm{~kg}$ body weight may be predicted from ration composition with the same error as from contents of digested quantities. However, the prediction of the amount of metabolisable energy present in a ration from content of crude fibre or lignin of the hay, and from type of concentrates used, gives less accurate figures than the determination of its content of metabolisable energy in a digestion experiment. The standard deviation of the metabolisability in an experiment is about $1-1.5$ units. The residual standard deviation of regression equations used to predict metabolisability from content of lignin or crude fibre of hay is about 2 or 3 . The determination of metabolisable energy thus has an error of $200-250 \mathrm{kcal}$., its prediction by regression gives an error of $400-500 \mathrm{kcal}$. The determination of $\mathrm{ME}$ and the prediction of the maintenance requirement for ME per $500 \mathrm{~kg}$ body weight from crude fibre content gave a total RSD of about $570 \mathrm{kcal}$. Prediction of ME and of maintenance requirement probably gives a total RSD of about $V\left(570^{2}-225^{2}+450^{2}\right)$ $=760 \mathrm{kcal}$. Because both figures are high, the difference between them is relatively small. However, to the animal itself the difference is relatively much greater. If the amount of metabolisable energy of a ration has been measured, the animal may be fed with an error of 200-250 kcal. metabolisable energy, if the amount of metabolisable energy of the ration is predicted, it may be fed with an error of 400-500 kcal. Small changes in the animal's ability to convert metabolisable energy into net energy and small changes in its maintenance requirement are the only other reasons why a known quantity of a ration does not always give exactly the same production above maintenance. The additional error produced in predicting the content of metabolisable energy thus for the animal is relatively much greater.

When the net energy content of a food can be computed by regression on e.g. its crude fibre content with $10-20 \%$ greater RSD than by regression on \% digestible dry matter, it is tempting to accept the lower accuracy of the former method in view of the amount of work saved if only crude fibre has to be determined. From similar considerations ARMSTRONG et al. (1964) suggested that for advisory purposes simple chemical analysis should be preferred, despite the slightly less precise estimate obtained when compared with methods based on digestibility determinations. In our opinion, however, one should be careful in accepting slightly higher RSD's since in energy balance experiments the RSD's usually consist for a large part of errors of measurement, which overshadow the physiological errors.

\subsection{Variation of the maintenance requirement of metabo-} lisable energy due to the composition of the ration

Replacement of the ten rations as ten variables in the regression computations by the contents of some components of the rations as variables resulted in a 30-35\% increase of residual variance. Obviously it was not possible to describe all the properties of the rations in this manner. Better results might be obtained if instead of the components digested crude fibre and digested $\mathrm{N}$-free extractives better defined components could be used, such as the groups digested cellulose, digested branched and non-branched hemicelluloses, and digested other carbohydrates.

In general the maintenance requirement for metabolisable energy $\left(M_{u, 500}\right)$ decreased with increasing digestibility both in the present and in the earlier series of experi- 
ments. Decreases of similar size were found by ARMSTrong (1964), with artificially dried grasses, and by BREIREM (1944) in a computation of experiments performed by various investigators before 1940. The size of the variation, however, is small if compared with the ration variation in lipogenesis. In our experiments $\mathbf{R} 16-62$ an increase in the metabolisability of one unit decreased $M_{m, 500}$ by $72 \mathrm{kcal}$, i.e. $0.6 \%$ of $M_{m, 500}$. According to Blaxter's equation $E=0.94 m-8$ (BLAXTER, 1962, p. 247), the efficiency $E$ of the utilisation of metabolisable energy for lipogenesis changes by 0.94 per unit metabolisability $(m)$, i.e. with about $2 \%$ of the average $E$. From the figures of ARMSTrong (1964), on the efficiency of the utilisation of metabolisable energy for maintenance $\left(E_{m}\right)$ and for lipogenesis $\left(E_{f}\right)$ of twelve artificially dried grasses, we computed the following regression equations $\left(x_{1}=\right.$ digestibility of energy, $x_{2}=$ percentage of proteincalories in digested energy):

$E_{m}=(0.32 \pm 0.09)\left(x_{1}-73.26\right)+73.21$

$E_{m}=(0.56 \pm 0.14)\left(x_{1}-73.26\right)-(0.41 \pm 0.21)\left(x_{2}-17.21\right)+73.21$

(RSD 2.2)

$E_{f}=(0.56 \pm 0.15)\left(x_{1}-73.26\right)+48.03$

$E_{f}=(0.21 \pm 0.24)\left(x_{1}-73.26\right)+(0.63 \pm 0.36)\left(x_{2}-17.21\right)+48.03$

(RSD 3.6)

If $x_{1}$ is increased by one unit, the $E_{m}$-figures change only with 0.32 or $0.4 \%$ of the average $E_{m}$, the $E_{f}$-figures with 0.56 or $1.2 \%$ of average $E_{f}$. As stated above the variation due to ration is much higher for lipogenesis than for maintenance. The size of the variation of $E_{m}$ as found by Blaxter (see ARMstrong, 1964) in his experiments with hay- and mixed rations differed hardly from the variation of $E_{m}$ in Armstrong's experiments, again the variation of $E_{f}$ was much higher.

In the present experiments the residual sum of squares hardly decreased when the absence or presence of concentrates in the ration was added as a variable in the regression computations. Blaxter and Breirem dealing also with mixed rations found the same results as Armstrong and ourselves. Obviously the absence or presence of concentrates as such plays no important role in maintenance requirement.

The influence of digestible calories originating from protein on $M_{m, 500}$ is not completely clear. Theoretically it might be expected that a high proportion of digestible energy of protein origin would result in a higher excretion of urea which might require additional energy (BLAXTER, 1962, p. 248). Indeed, in the present series the maintenance requirement increased significantly with increasing level of digestible calories of protein origin, a similar effect occurred in Armstrong's experiments with artificially dried hays. In our earlier experiments with rations of hay there was only a tendency toward such an influence; when all our experiments are considered together the influence is significant.

The rule of increased requirement of $\mathrm{ME}$ for maintenance due to lower digestibility probably does not always hold true for rations containing silage. Preliminary results of some recent experiments showed a decrease of requirement if the silage of a mixed ration was replaced by hay having a lower digestibility than the silage; not all silages, however, behaved in this way. 


\section{ACKNOWLEDGEMENTS}

The experiments were performed while Professor Dr. E. Brouwer was director of the institute. Professor Brouwer took part in the planning of the experiments and also in some of the routine determinations and computations.

Thanks are due to Mr. H. van Dijk for production of the hays, to Mr. J. E. Vogt, Mr. R. Terluin and Mr. E. Ruisch for care of the animals and performance of respiration and digestion trials and to Miss R. Janse, Miss A. Nachtegaal, Mrs. W. TerluinVan der Brugge, Mr. J. Lange and Mr. J. Bouman for analytical work. The conscientious work of this whole team is recognized with due respect.

We wish to thank the Director and the Staff of the Statistical Department of the Agricultural University, Wageningen, for valuable advice given while using their electronic computer.

Thanks are due to $\mathrm{Mr}$. M. Gee for revising the English text.

Armstrong, D. G.

Armstrong, D. G., BLAXTER, K. L. and WAITE, R.

BLAXTER, K. L.

BREIREM, K.

Brouwer, E., van Es, A. J. H. and NiJKamp, H. J.

Es, A. J. H. vaN

Es, A. J. H. van, BrouwEr, E. and NiJKamp, H. J. Es, A. J. H. vaN

Schiemann, R., NeHring, K. und HofFmanN, L.

\section{REFERENCES}

1964 Evaluation of artificially dried grass as a source of energy for sheep. Part 2. J. Agric. Sci. 62, 399-416.

1964 Evaluation of artificially dried grass as a source of energy for sheep. Part 3. J. Agric. Sci. 62, 417-424.

1962 The Energy Metabolism of Ruminants. Hutchinson, London.

1944 Grunnlaget for Fôrmiddelvurderingen. Kgl. Lantbruksakad. Tidsskr. 83, 345-408.

1964 The feeding value of early cut and late cut hay for the maintenance of cows. Meded. Landbouwhogeschool, Wageningen, 64, 9.

1961 Between-animal variation in the amount of metabolisable energy required for the maintenance of cows. Versl. Landbouwk. Onderz. 67, 5.

1964 The feeding value for the maintenance of cows of hay from six parts of The Netherlands. Proc. 3rd Symp. Energy Metabolism, Troon, pp. 95-110.

1966 Labour-saving methods for energy balance experiments with cattle; description of equipment and methods used. Neth. J. Agric. Sci. 14, 32-46.

1963 Die energetische Verwertung der Futterstoffe. Teil 5. Archiv Tierernähr. 13, 177. 